\title{
A Comparison Using Gel Electrophoresis of Cell Proteins of Campylobacters (Vibrios) Associated with Infertility, Abortion and Swine Dysentery
}

\author{
By J. A. MORRIS* AND R. W. A. PARK \\ Department of Microbiology, Reading University, London Road, \\ Reading, $R G$ I $5 A Q$
}

(Received 22 March 1973)

\begin{abstract}
SUMMARY
Ninety-six campylobacters were isolated from cattle, sheep, pigs and fowls, of which 40 were studied in detail. Characterization by routine biochemical tests indicated that all isolates were similar and that differences did not correspond with habitat or pathogenicity. The electrophoresis patterns of acid plus phenol-soluble proteins from the 40 campylobacters allowed the isolates to be placed in three groups which correlated with habitat. Group I comprised all the campylobacters from the bovine genital tract (these isolates were associated with infertility). Group II comprised all the strains isolated from cattle faeces and all the strains associated with sporadic abortions in cattle and sheep. Group III comprised all the campylobacters from healthy pigs and from pigs with swine dysentery. Isolates could not be differentiated by electrophoresis of total soluble proteins. Isocitrate dehydrogenase and peroxidase electrophoresis patterns each allowed the pig campylobacters to be differentiated from cattle and sheep campylobacters, but did not allow finer differentiation. Malate dehydrogenase patterns, which were produced only by the pig campylobacters, provided three groups but these did not correlate with isolation source. It is concluded that there is no qualitative difference in the campylobacter population of the gut of healthy and dysenteric pigs.
\end{abstract}

\section{INTRODUCTION}

Campylobacters (microaerophilic vibrios; Sebald \& Véron, I963) cause infectious infertility and abortion in cattle and abortion in sheep. The organisms are associated with swine dysentery, though their role in the disease is not clear, and have been isolated from sources such as the vagina of women at fertility clinics (Moore, 1954), goats (Lawson, 1959), the domestic fowl (e.g. Whenham, Carlson \& Askel, 196I), wild birds (Watson, Hunter \& Bellhouse, 1967) and rats (Pejtschev, 1969). In most differential tests employed for bacteria campylobacters appear to be relatively inert; they do not attack the usual range of carbohydrates, hydrolyse gelatin, starch, urea or lipid, haemolyse blood nor produce indole, but nitrite is produced from nitrate.

Florent (1953, I957, I959) subdivided campylobacters from cattle, sheep and pigs on the basis of catalase production, growth in the presence of $\mathrm{x} \cdot 0 \%$ glycine, production $\mathrm{of}_{2} \mathrm{H}_{2} \mathrm{~S}$ from a medium containing cystine and their isolation site and pathogenicity (see Table I). Park, Munro, Melrose \& Stewart (I962) studied campylobacters, which corresponded biochemically to Florent's Campylobacter fetus var. intestinalis, from the genital tract of heifers with histories of infertility and showed that they could proliferate in the genital tract

* Present address: Ministry of Agriculture, Fisheries and Food, Central Veterinary Laboratory, Weybridge, Surrey. 
Table I. Characteristics proposed by Florent to differentiate Campylobacter fetus varieties

\begin{tabular}{|c|c|c|}
\hline Characteristic & $\begin{array}{l}\text { C. fetus var. } \\
\text { intestinalis }\end{array}$ & $\begin{array}{c}\text { C. fetus var. } \\
\text { venerealis }\end{array}$ \\
\hline $\mathrm{H}_{2} \mathrm{~S}$ production from medium containing $0.02 \%$ cystine & + & - \\
\hline Growth in presence of $\mathrm{I} \cdot 0 \%$ glycine & + & - \\
\hline Causes infectious infertility in cattle & - & + \\
\hline $\begin{array}{l}\text { Causes sporadic abortion in cattle and abortion storms } \\
\text { in sheep, but not infertility in cattle }\end{array}$ & + & - \\
\hline $\begin{array}{l}\text { Ability to proliferate in genital tract of non-pregnant } \\
\text { heifer }\end{array}$ & - & + \\
\hline $\begin{array}{l}\text { Normal habitat intestinal tract of cattle and other } \\
\text { animals }\end{array}$ & + & - \\
\hline
\end{tabular}

of non-pregnant heifers. These findings, later confirmed by Florent (1963), showed that because some strains behaved in vivo like Florent's $C$. fetus var. venerealis, but gave the biochemical reactions of $C$. fetus var. intestinalis, separation on the basis of the biochemical tests shown in Table I was not always satisfactory. Morris (I97I) found that all the campylobacter isolates obtained from both healthy pigs and pigs suffering from swine dysentery biochemically resembled $C$. fetus var. intestinalis, differing only in producing more $\mathrm{H}_{2} \mathrm{~S}$. But Söderlind (1965) found that many isolates from pigs showed no serological cross-reaction with $C$. fetus.

The biochemical tests currently used to classify campylobacters are not wholly satisfactory and so we have looked for other means of differentiation. This communication describes electrophoretic studies of various protein components of campylobacter, undertaken in the hope of detecting differences between strains, and discusses the results in the light of differences in habitat and association with disease. Campylobacter bubulus was not examined because it is not usually associated with disease and because lack of catalase differentiates it from other campylobacters (Thouvenot \& Florent, 1954). A preliminary report of this work has been published (Morris \& Park, 1970).

\section{Strains}

\section{METHODS}

Campylobacters, whose histories are given in Table 3, were isolated as described earlier (Morris \& Park, 197I). Escherichia coli was strain 16A from our departmental collection and the aerobic vibrio was a member of Gardner \& Venkatraman ' $O$ ' subgroup 6 (NCTC 47I6).

\section{Characterization of isolates}

With the exception of nutrient gelatin, which was prepared according to Cruickshank (I965), each test medium was prepared by adding the appropriate solid test compound (Table 3) to freshly reconstituted Albimi brucella broth (ABB: Micro-Bio Labs, 46 Pembridge Road, London, W. II) made semisolid by the addition of Agar no. 3 (Oxoid; Southwark Bridge Road, London, S.E. I) (0.1\%, w/v). Hydrogen sulphide and glycine tolerance tests were described by Park et al. (I962). Catalase production was demonstrated by effervescence on the addition of $0.5 \mathrm{ml}$ of 10 vol. $\mathrm{H}_{2} \mathrm{O}_{2}$ to growth in semisolid ABB. Gelatin liquefaction and reduction of nitrate (in semisolid $\mathrm{ABB}+\mathrm{KNO}_{3}, 0 . \mathrm{I} \%, \mathrm{w} / \mathrm{v}$ ) were tested by standard procedures (Cruickshank, 1965). Glucose fermentation was tested by measuring the $\mathrm{pH}$ value of cultures in semisolid $\mathrm{ABB}+\mathrm{D}(+)$-glucose $(0 \cdot \mathrm{I} \%$, w/v) using narrow-range $\mathrm{pH}$ 
paper. All incubations were at $37^{\circ} \mathrm{C}$ and, with the exception of the $\mathrm{H}_{2} \mathrm{~S}$ tests, which were examined daily (Park et al. 1962), the cultures were examined after incubation for 7 days.

\section{Electrophoretic studies}

Bulk growth and harvesting of bacteria. Campylobacters were grown in $250 \mathrm{ml}$ conical flasks containing $100 \mathrm{ml} \mathrm{ABB}$. Each flask was inoculated with $10 \mathrm{ml}$ of an exponential phase culture in semisolid $\mathrm{ABB}$, filled with an atmosphere of $30 \%(\mathrm{v} / \mathrm{v}) \mathrm{CO}_{2}$ in air, and the plug tightly covered with aluminium foil to reduce gaseous exchange. The aerobic vibrio and Escherichia coli were grown aerobically in nutrient broth. Incubation was at $37^{\circ} \mathrm{C}$ on a Gallenkamp orbital shaker operating at $150 \mathrm{rev} . / \mathrm{min}$. Bacteria from $1500 \mathrm{ml}$ of late exponential-phase culture were harvested by centrifugation at $\mathrm{I} 8000 \mathrm{~g}$ for $10 \mathrm{~min}$ at $4{ }^{\circ} \mathrm{C}$ and washed twice in quarter strength Ringer's solution.

Preparation of protein fractions. Two protein fractions were studied: (a) total soluble proteins, and $(b)$ acid + phenol soluble proteins, both usually being prepared from the same batch of cells. Packed cells, resuspended to $250 \mathrm{mg}$ wet $\mathrm{wt} / \mathrm{ml}$ in phosphate-buffered saline ( $100 \mathrm{mM}, \mathrm{pH} 7 \cdot 0$ ), were broken by ultrasonic treatment in $40 \mathrm{ml}$ amounts in a Rosett (1965) cell surrounded by a slurry of melting ice. The $100 \mathrm{~W}$ ultrasonic disintegrator (MSE, Manor Royal, Crawley, Sussex) was fitted with a 0.75 in. titanium probe and operated at $20 \mathrm{kHz}$ giving a wavelength of about $6.2 \mu \mathrm{m}$ peak to peak. Treatment was for $4 \times \mathrm{I}$ min, the probe being swtiched off during every alternate minute to aid cooling. After centrifugation at $40000 \mathrm{~g}$ for $30 \mathrm{~min}$ at $4{ }^{\circ} \mathrm{C}$ the supernatant fluid, hereafter called the 'total soluble protein sample', was decanted and the protein content determined using Kennedy \& Fewson's (I968) modification of the Lowry method. The pellet was washed twice in Ringer's solution and resuspended to about 2 to $3 \mathrm{ml}$. The amount of protein was determined and the suspension adjusted to give Io $\mathrm{mg}$ protein $/ \mathrm{ml}$ Ringer's solution. To I vol. of this suspension was added 2 vol. phenol + acetic acid + water (4:2:I parts by weight) and the mixture left at room temperature overnight. The digest was centrifuged in an identical manner to the sonicated suspension and the resulting supernatant fluid, hereafter called the 'acid + phenol soluble (APS) protein sample', was retained. The pellet was discarded. Both the total soluble protein samples and the APS protein samples were frozen at $-20^{\circ} \mathrm{C}$ if they were not required immediately.

Preparation of gels. Gels to separate total soluble proteins were prepared by a modification of the method of Davis (I964). One vol. solution A (tris, $36.3 \mathrm{~g}$; I M-HCl, $48 \cdot 0 \mathrm{ml}$; $N, N, N^{\prime}, N^{\prime}$-tetramethylethylene-diamine, $\mathrm{I} \cdot 0 \mathrm{ml} ; \mathrm{H}_{2} \mathrm{O}$ to $\mathrm{I} 00 \mathrm{ml}$ ) was mixed with 2 vol. solution B (acrylamide, 30.0 g; $N, N^{\prime}$-methylenebisacrylamide, $0.8 \mathrm{~g}$; potassium ferricyanide, $0.0 \mathrm{I} 5 \mathrm{~g} ; \mathrm{H}_{2} \mathrm{O}$ to $\mathrm{I} 00 \mathrm{ml}$ ), and 4 vol. solution $\mathrm{C}$ (ammonium persulphate, $0.3 \mathrm{~g} ; \mathrm{H}_{2} \mathrm{O}$ to $\mathrm{I} 00 \mathrm{ml}$ ) and I vol. $\mathrm{H}_{2} \mathrm{O}$, and was left for $\mathrm{I} h$ at room temperature to polymerize. Gels to separate APS proteins were prepared by a modification of the method of Razin \& Rottem (1967). Twelve millilitres of solution D (urea, $30.0 \mathrm{~g}$; acrylamide, $7.5 \mathrm{~g} ; N, N^{\prime}$-methylenebisacrylamide, $0.2 \mathrm{~g} ; 35 \%(\mathrm{v} / \mathrm{v})$ aqueous acetic acid to $100 \mathrm{ml}$ ) was added to $10 \mathrm{mg}$ ammonium persulphate in a Buchner flask, which was then evacuated to I6o Torr and shaken occasionally during $5 \mathrm{~min}$. The vacuum was released and $0.04 \mathrm{ml}$ of $N, N, N^{\prime}, N^{\prime}$-tetramethylethylenediamine was added and distributed by gently rotating the flask. Polymerization was at $37^{\circ} \mathrm{C}$ for $90 \mathrm{~min}$. Both types of gel were cast by pipetting into glass running tubes $(75 \mathrm{~mm} \times 5 \mathrm{~mm})$ to a height of $62 \mathrm{~mm}$ and layering a few drops of water (for soluble protein) or $75 \%(\mathrm{v} / \mathrm{v}$ ) aqueous acetic acid (for APS protein) on the surface of the gels. Tubes were positioned vertically in an Analytical Polyacrylamide Electrophoresis Apparatus (Shandon, Pound 
Table 2. Mixtures for the detection of enzymes

Enzyme to be detected

Malate dehydrogenase

Isocitrate dehydrogenase

Peroxidase
Reagents

Quantity

(ml)

Clark-Lubs buffer ( $50 \mathrm{~mm}$ ), $\mathrm{pH}$ I0.0

MTT tetrazolium* (2.4 mM)

$N$-methylphenazonium methosulphate, PMS (I mM)

NAD (I $4 \mathrm{~mm}$ )

Sodium malate $(\mathrm{I} \cdot 5 \mathrm{M})$

Tris- $\mathrm{HCl}$ buffer (100 mM), pH 8.5

MTT tetrazolium $(2 \cdot 4 \mathrm{~mm})$

PMS (I mM)

NADP ( 3 mM)

Magnesium chloride (100 mM)

Sodium isocitrate (1 $3.5 \mathrm{~mm})$

Tris-HCl buffer ( I OO mM), $\mathrm{pH} 7 \cdot \mathbf{I}$

Pyrogallol (20 mM)

Hydrogen peroxide (0.74 $\mathrm{mm})$
$5 \cdot 0$

$2 \cdot 0$

$\mathrm{I} \cdot \mathrm{O}$

$1 \cdot 0$

$\mathrm{I} \cdot \mathrm{O}$

$4 \cdot 2$

$2 \cdot 0$

$1 \cdot 0$

0.8

$1 \cdot 0$

$1 \cdot 0$

6.0

$3 \cdot 0$

$\mathrm{I} \cdot \mathrm{O}$

* 3-(4,5-dimethyl thiazolyl-2)-2,5 diphenyl tetrazolium bromide.

Lane, London, N.W. 10) and the reservoir fluid added (for soluble protein: glycine, $28.8 \mathrm{~g}$; tris, $6.0 \mathrm{~g} ; \mathrm{H}_{2} \mathrm{O}$ to $\mathrm{I} 1$; for APS protein: $10 \%$ (v/v) aqueous acetic acid).

Application of sample. Samples containing 250 to $300 \mu \mathrm{g}$ protein were applied through the reservoir fluid using $\mathrm{I} .0 \mathrm{ml}$ disposable syringes fitted in a home-made calibrated screw device. Soluble protein samples contained (per $0.1 \mathrm{ml}$ ) $0.02 \mathrm{ml}$ aqueous bromophenol blue $(0.1 \%, \mathrm{w} / \mathrm{v})$ and $0.18 \mathrm{ml}$ sucrose-Sephadex (Broome, I963); APS protein samples were applied without these additions. Following Clarke (r964) no spacer gel was used.

Electrophoretic separation of sample. For soluble protein fractions the upper electrode was made the cathode and a constant current equivalent to $5 \mathrm{~mA} /$ gel supplied from a Vokam type 254r Power Pack (Shandon). Electrophoresis was usually terminated when the bromophenol blue, assumed to move with the chloride-glycinate interface, had migrated about 45 to $55 \mathrm{~mm}$ into the gel. For APS protein fractions the upper electrode was made the anode and a constant current equivalent to $3 \mathrm{~mA} / \mathrm{gel}$ was delivered for $30 \mathrm{~min}$, followed by $5 \mathrm{~mA} /$ gel for $40 \mathrm{~min}$. To allow comparison of proteins run on different occasions one of the gels in each run was always used for protein from a reference strain (H22).

Staining of APS proteins and soluble proteins was by $\mathrm{I} \cdot 0 \%$ Amido Black prepared in $7.0 \%(\mathrm{v} / \mathrm{v})$ aqueous acetic acid, unbound stain being removed after $60 \mathrm{~min}$ by washing in $3.0 \%(\mathrm{v} / \mathrm{v})$ aqueous acetic acid contained in a bath fitted with a stirring device.

Detection of enzymes in soluble protein preparations. At the completion of electrophoresis unstained gels containing soluble proteins were expelled from the running tubes, quickly dried with filter paper and put into specimen tubes. Equal volumes of the enzyme reaction mixture and $2.0 \%(\mathrm{w} / \mathrm{v})$ aqueous molten Agar no. I (Oxoid) were mixed at $50^{\circ} \mathrm{C}$ and poured into the specimen tubes to cover the gel (Table 2). Gels were incubated at $37^{\circ} \mathrm{C}$ in the dark until the colour developed, and were photographed within to min.

\section{RESULTS}

\section{Isolation and biochemical characterization}

Ninety-six campylobacters were isolated from cattle, sheep, pigs and fowls, and 40 of these isolates were kept for detailed study. All produced catalase and reduced nitrate to nitrite, but did not produce acid from glucose, grow in nutrient gelatin or haemolyse blood. Other biochemical characteristics and the history of each isolate are given in Table 3. Three 

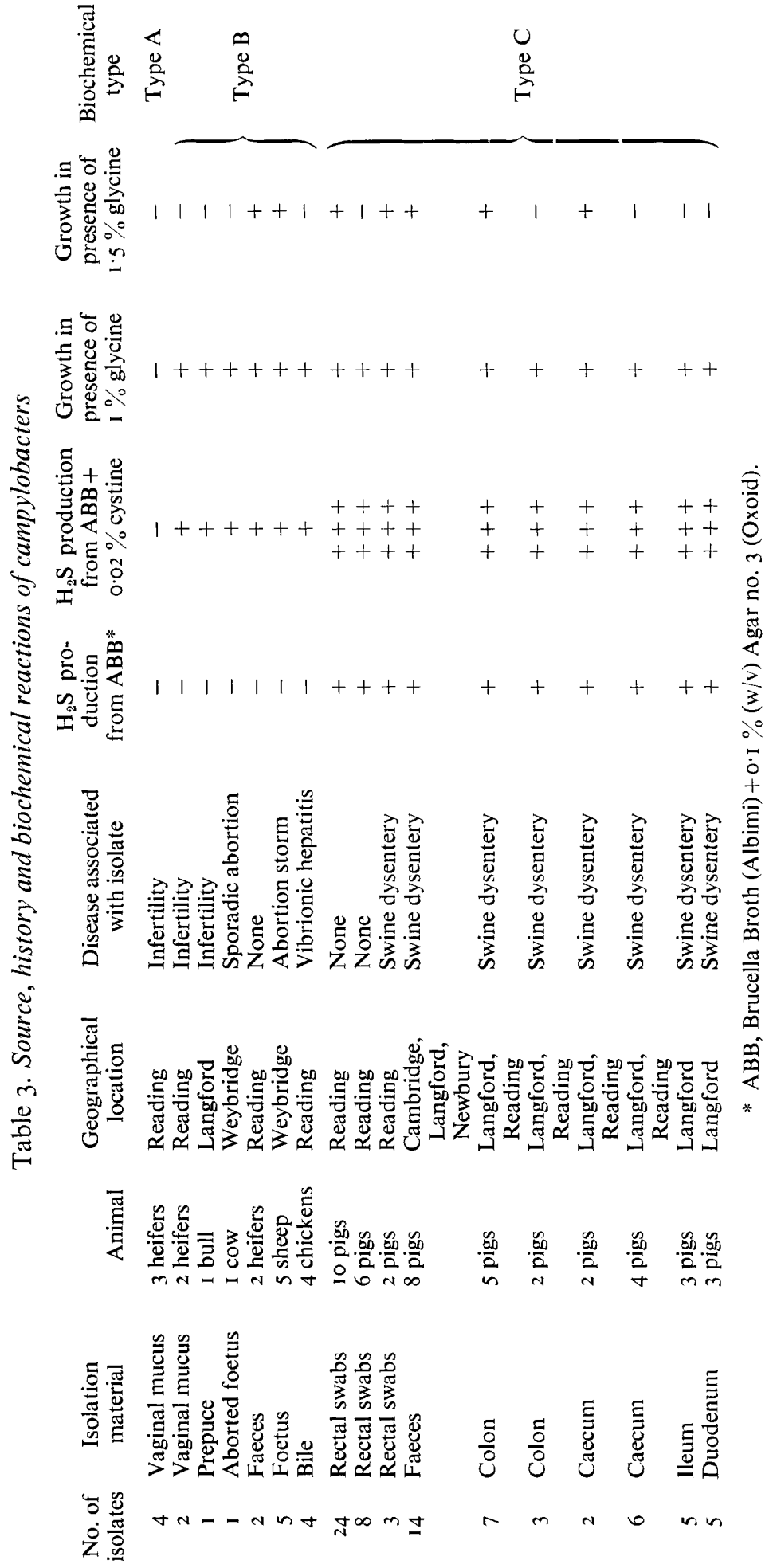
Table 4. Correlation between isolation sites, biochemical characteristics and electrophoresis patterns of cell proteins of campylobacters

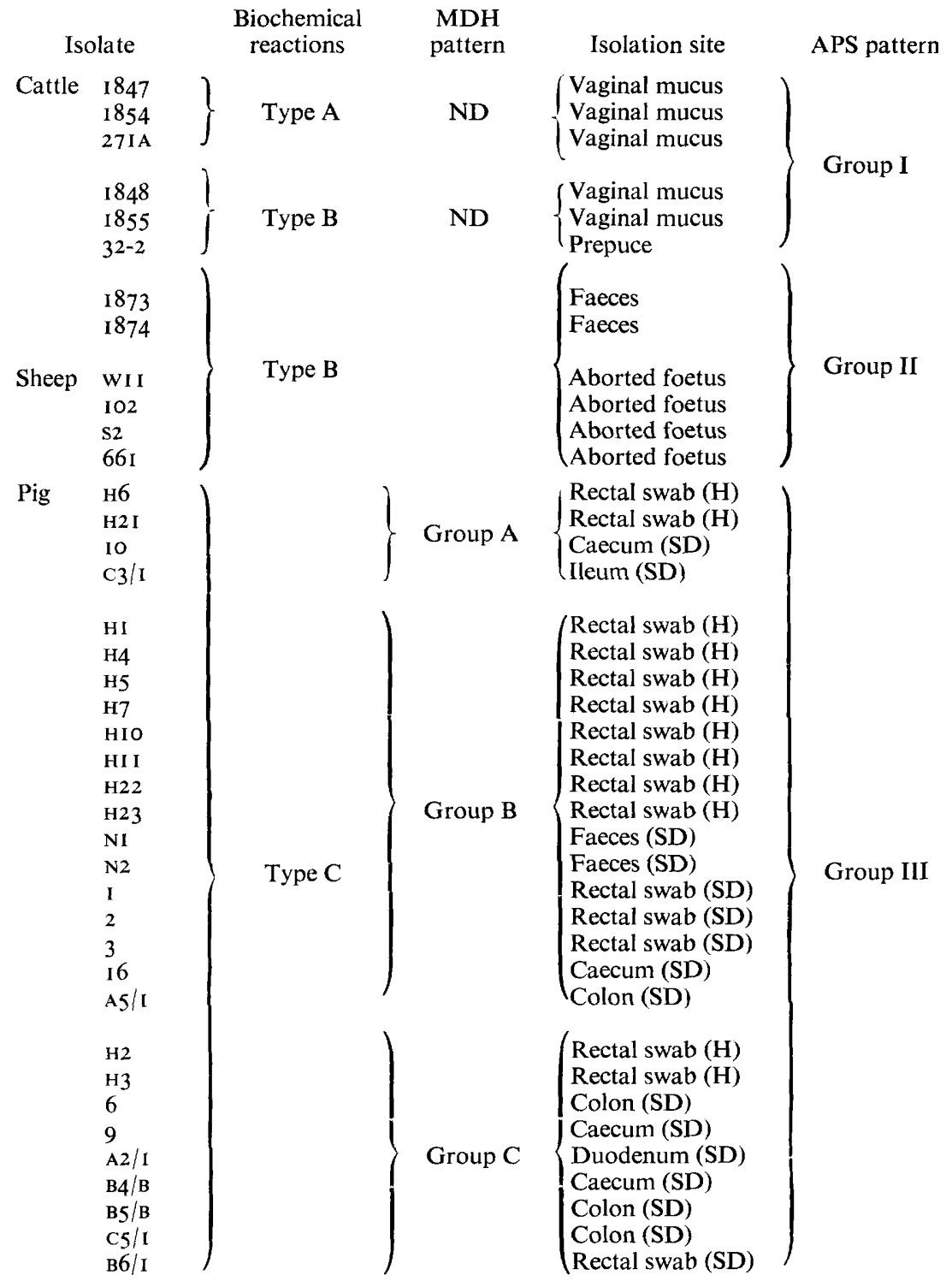

$\mathrm{ND}$, not detectable; $\mathrm{H}$, healthy animal; SD, swine dysentery; $\mathrm{MDH}$, malate dehydrogenase; APS, acid + phenol soluble proteins.

biochemical types were found. Type A did not produce $\mathrm{H}_{2} \mathrm{~S}$ from semisolid ABB or semisolid ABB + cystine within 7 days, nor grow in the presence of $1.0 \%$ or $1.5 \%$ glycine. This type biochemically resembled Campylobacter fetus var. venerealis (Florent, I959). Type B produced $\mathrm{H}_{2} \mathrm{~S}$ from semisolid $\mathrm{ABB}+$ cystine within 3 days, but not from semisolid $\mathrm{ABB}$ even after 7 days, and grew in the presence of $\mathrm{I} \cdot 0 \%$ glycine. The three Type B isolates from the bovine genital tract were unable to tolerate $1.5 \%$ glycine, but all the other ovine and 


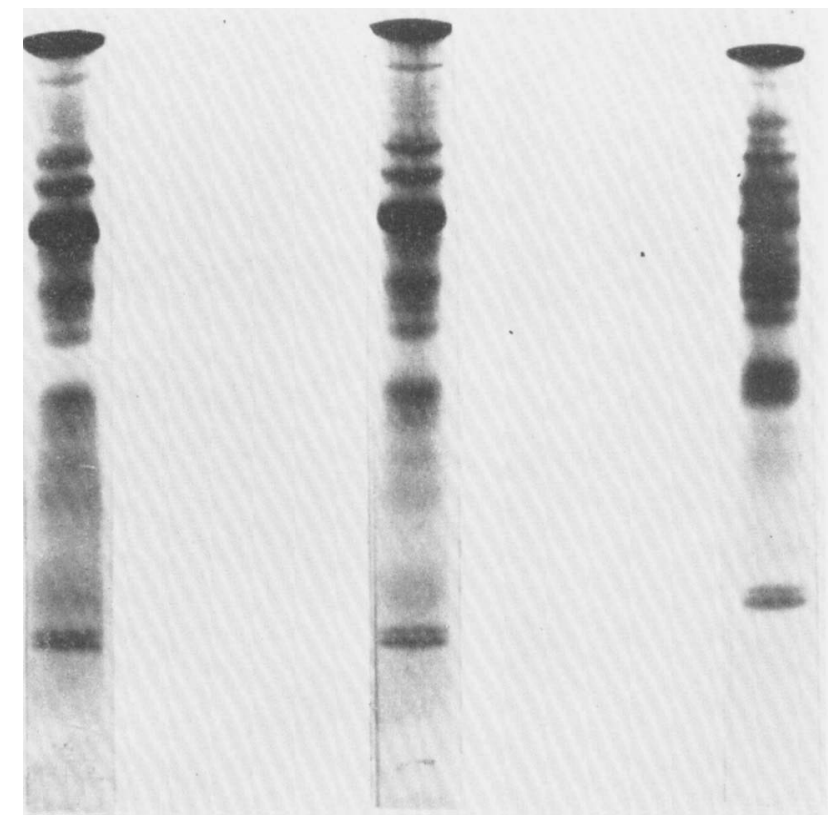

(a)

(b)

(c)

Fig. 1. Electrophoresis of total soluble protein from (a) Campylobacter $\mathrm{H} 22$ from a rectal swab of ia healthy pig, (b) Campylobacter B4/B from the caecum of a pig with swine dysentery, and (c) Escherichia coli.

bovine Type B campylobacters did tolerate this. Type B isolates biochemically resembled C. fetus var. intestinalis (Florent, I959). Type $\mathrm{C}$ produced copious amounts of $\mathrm{H}_{2} \mathrm{~S}$ from semisolid $\mathrm{ABB}+$ cystine, and some $\mathrm{H}_{2} \mathrm{~S}$ from $\mathrm{ABB}$ without added cystine, within 3 days, and grew in the presence of $\mathrm{I} .0 \%$ glycine. The majority of Type $\mathrm{C}$ isolates grew in the presence of $\mathrm{I} \cdot 5 \%$ glycine.

Type A strains were from bovine genitalia; Type B strains were from bovine genitalia, bovine and ovine aborted foetuses, bovine faeces and avian bile; and Type $\mathrm{C}$ strains were from the porcine gut. The name Vibrio coli was first applied by Doyle (1948) to campylobacters from the porcine gut but he stated that $V$. coli did not reduce nitrate. The species has not been formally transferred to the new genus Campylobacter and so its status is unclear.

\section{Electrophoresis}

Rigid standardization of procedure and protein concentration, and inclusion of a reference bacterial extract in each run, were essential for interpretation of electrophoresis patterns. At least three sets of samples were examined for each isolate. Photographs were the best permanent record, although not all the bands were visible on the prints; electronic plots of optical density of the gels were unsatisfactory.

Total soluble proteins. Strains gave identical patterns of total soluble proteins; even a strain of Escherichia coli gave a pattern which had few detectable differences from that of the campylobacters (Fig. I).

APS proteins. Using electrophoresis of APS protein campylobacters could be placed into three groups (Table 4). Group I comprised all the cattle genital campylobacters, regardless of biochemical characteristics. Group II comprised all the sheep campylobacters and all 


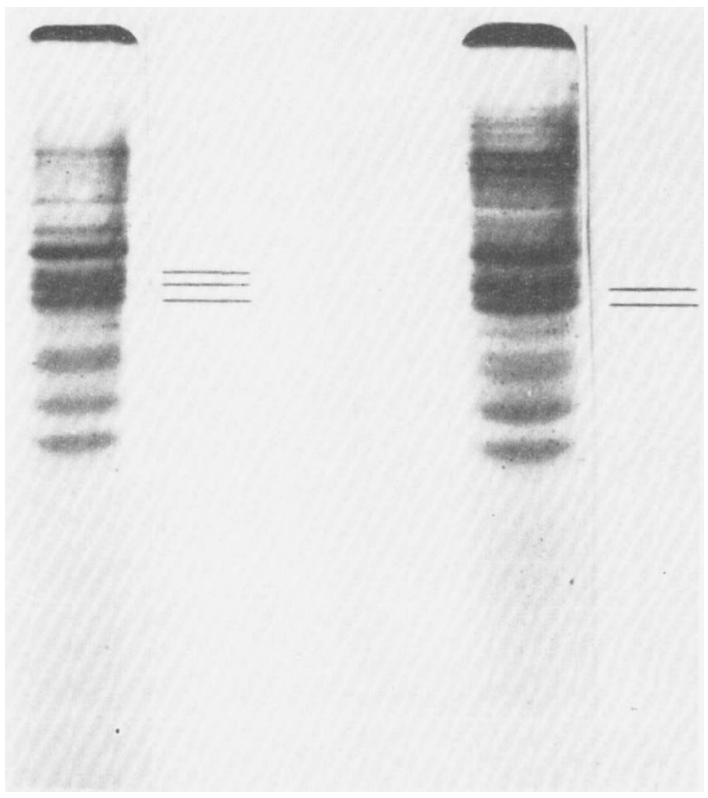

Fig. 2. Electrophoresis of APS protein of a Group I campylobacter from vaginal mucus of a heifer (Campylobacter 1848) and a Group II strain from faeces of a heifer (Campylobacter I874).

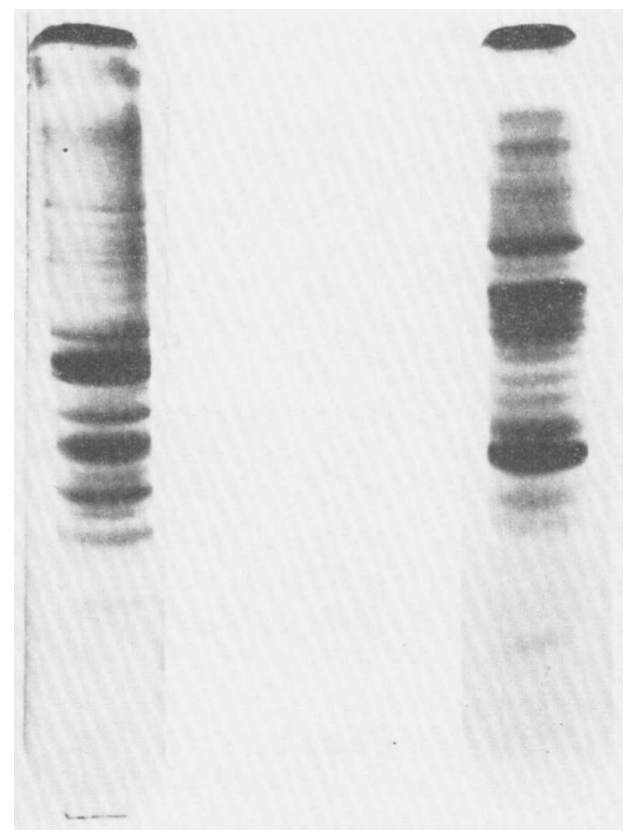

Fig. 3. Electrophoresis of APS protein of a Group II campylobacter from an aborted sheep foetus (Campylobacter WII) and a Group III strain from a rectal swab of a healthy pig (Campylobacter H22). 


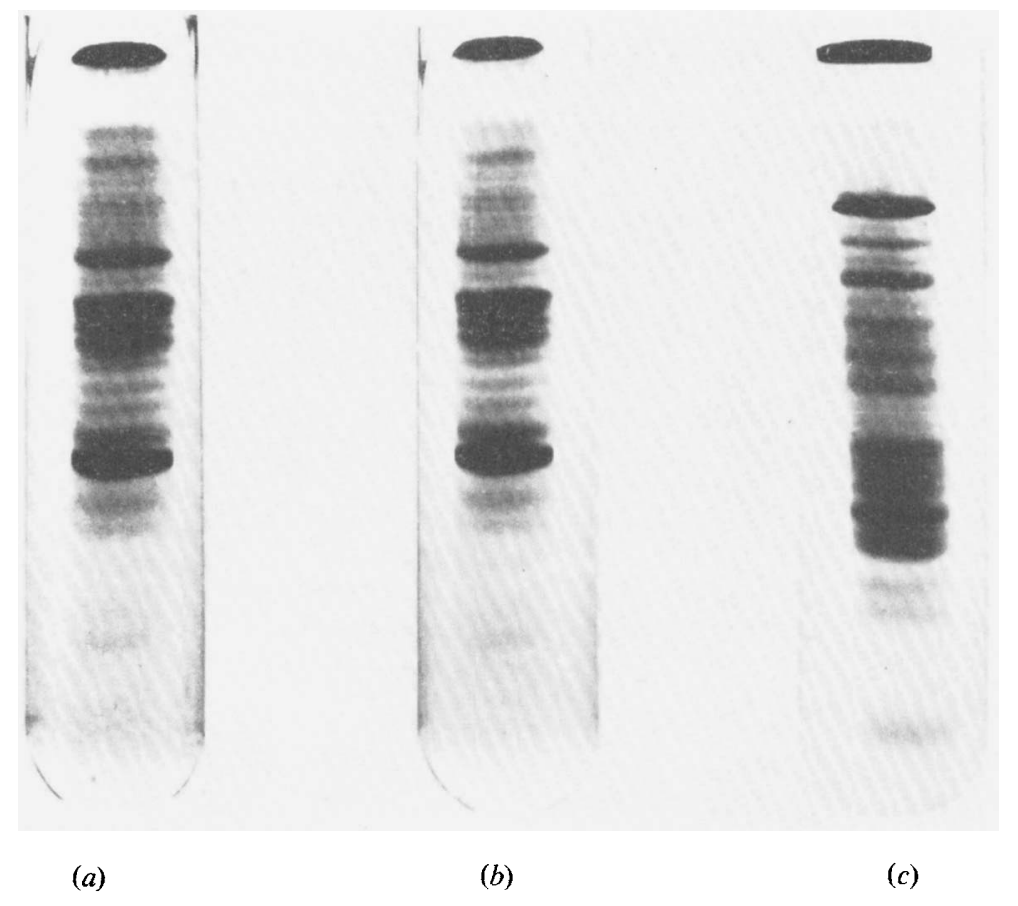

Fig. 4. Electrophoresis of APS protein from Group III campylobacters and Vibrio. (a) From a rectal swab of a healthy pig (Campylobacter $\mathrm{H22}$ ), $(b)$ from the caecum of a pig with swine dysentery (Campylobacter B4/B), (c) aerobic vibrio (NCTC 47I6).

the cattle faecal strains. Group I and Group II were very similar. Group III comprised all the pig campylobacters, regardless of glycine tolerance and anatomical site of isolation. Group III patterns were very different from Group I and Group II patterns. Fig. 2, 3 and 4 show the APS protein patterns of the three Groups. Fig. 4 also shows the APS protein pattern of an aerobic vibrio grown in nutrient broth.

Enzymes. Electrophoresis patterns of campylobacters from pigs differed from those from cattle and sheep in gels stained for malate dehydrogenase, isocitrate dehydrogenase and peroxidase. Faecal and genital campylobacters or cattle and sheep campylobacters could not be differentiated by patterns of enzyme activity.

All strains produced two isozymes of isocitrate dehydrogenase (ISD). The mobilities of pig campylobacter ISD were sufficiently greater than those of cattle and sheep strains (Fig. 5) to allow differentiation. One band of peroxidase activity was usually produced by pig campylobacters and two bands, both with greater mobility, by cattle and sheep strains (Fig. 6). Some preparations (WI I, I855, H3, H6, H22, 6) after storage or repeated freezing and thawing gave additional bands of activity (Fig. 7). Three malate dehydrogenase (MDH) patterns (referred to as MDH Group A, MDH Group B and MDH Group C) were found in pig campylobacters. All contained one major band, which was in an identical position in all groups, but the number and position of minor bands differed (Fig. 8). As with peroxidase preparations, additional bands of activity were observed in old $\mathrm{MDH}$ preparations. There was no correlation between MDH groups and anatomical or geographical isolation sources or the state of health of the pig (Table 4). Protein samples from cattle and sheep campylobacters, prepared in an identical manner to the porcine campylobacter extracts, had too 


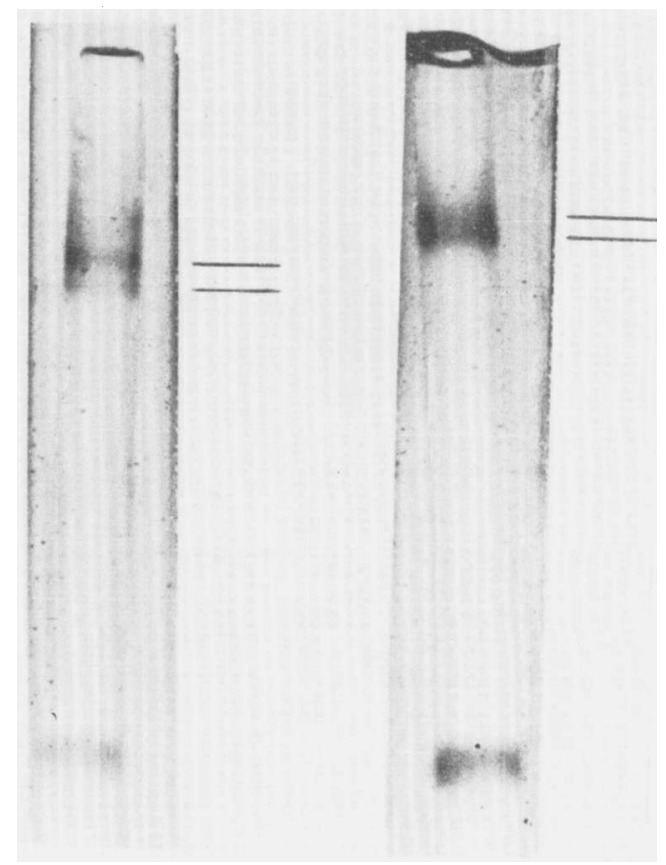

(a)

(b)

Fig. 5. Isocitrate dehydrogenase electrophoresis patterns of campylobacters, (a) from a pig (Campylobacter H22), (b) from a heifer (Campylobacter 1848).

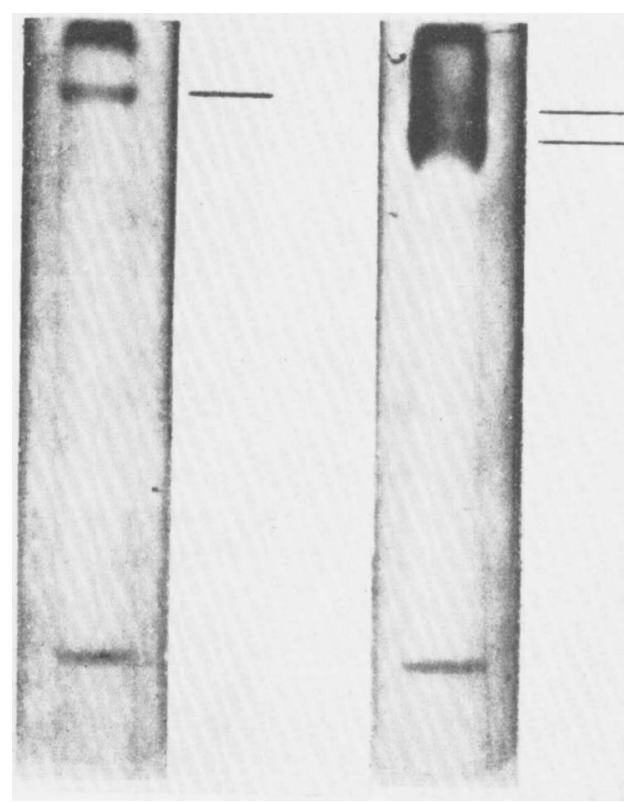

(a)

(b)

Fig. 6. Peroxidase electrophoresis patterns of campylobacters, (a) from a pig (Campylobacter H22), (b) from a heifer (Campylobacter 1848). 


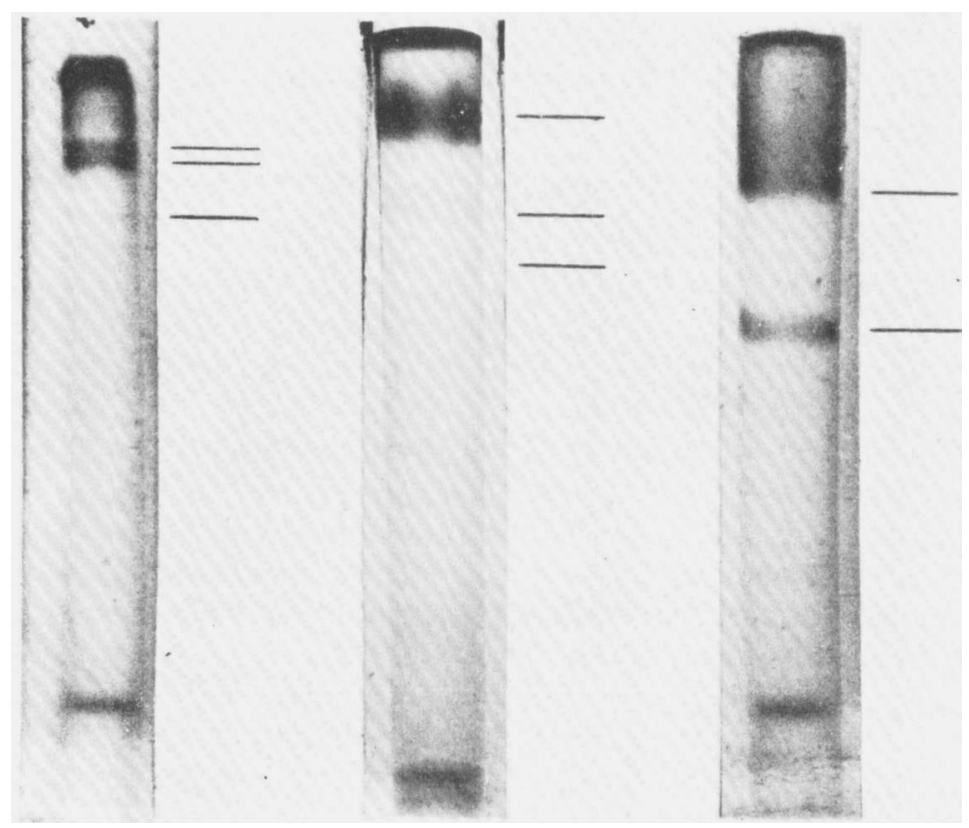

(a)

(b)

(c)

Fig. 7. Effect of freezing and thawing on peroxidase patterns of campylobacters, $(a)$ from a pig (Campylobacter H22), (b) from a pig (Campylobacter 6), (c) from a heifer (Campylobacter I855).

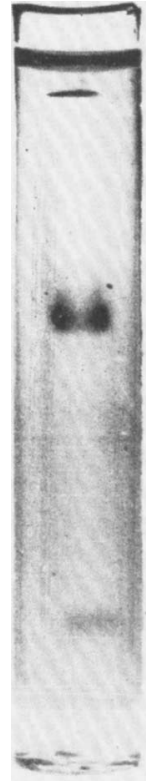

(A)

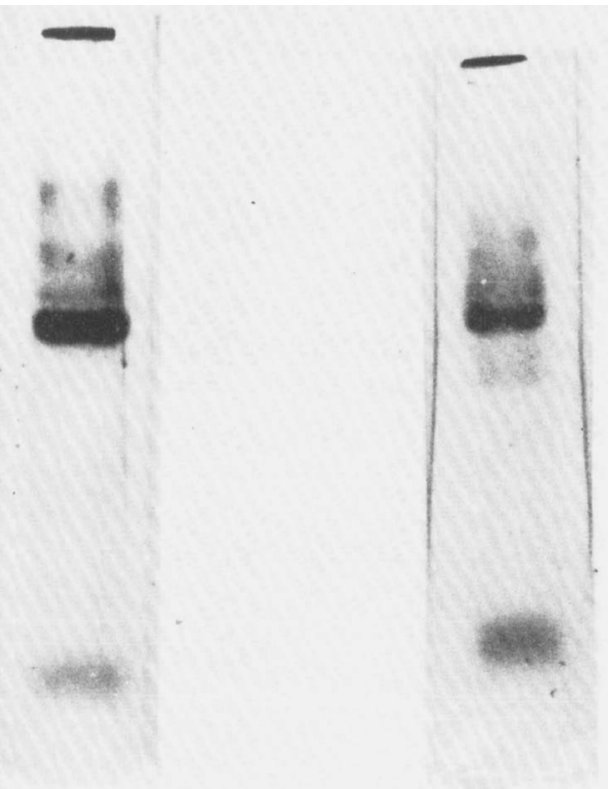

(B)
(C)

Fig. 8. Malate dehydrogenase electrophoresis patterns of pig campylobacters of Group A, Group B and Group C. Group A, Campylobacter 10. Group B, Campylobacter H22. Group C, Campylobacter 6. 
little malate dehydrogenase for detection on the gel. This was not a reflexion of the situation in the whole cell since respiration experiments with an oxygen electrode indicated that all the campylobacters studied oxidized malate at comparable rates (Morris, I97I).

\section{DISCUSSION}

There is no clear classification of the catalase-positive, microaerophilic vibrios despite many studies, including those of Bond (1957) using colony morphology; Mohanty, Plumer \& Faber (I962) using tolerance to $\mathrm{NaCl}$, glucose and formate; King (I962) using optimal growth temperatures; Plastridge, Williams \& Trowbridge (I964) using antibiotic sensitivity; and Firehammer \& Border (I968) using phage typing. In the biochemical tests now most commonly used for these organisms we found no correlation between the reactions and association with disease.

Norris (1964), by studying the isozymal forms of esterase on starch gels, clearly demonstrated that the distribution of different forms of esterase among bacteria could be of value in taxonomic studies. Electrophoresis of enzymes and total proteins has now been used in both the identification and classification of bacteria. Lund (1965) demonstrated differences at the species level by examining by gel electrophoresis water-soluble proteins of some group D streptococci. Razin \& Rottem (I 967) examined phenol-acetic-acid extracts of Mycoplasma membranes and reported that species-specific patterns were produced in polyacrylamide gels. Haas, Davidson \& Sacks (1972) found that a similar technique was of little value in differentiating Mycobacterium; but Sacks, Haas \& Razin (I969) reported that gel electrophoresis of phenol-acetic-acid extracts of Enterobacteriaceae differentiated the family mainly at the generic level. In our studies with campylobacters electrophoresis differentiated at three levels. Electrophoresis of the soluble protein differentiated campylobacters from Escherichia coli, but did not differentiate between campylobacters. APS protein differentiated between large groups of campylobacters, and some enzyme electrophoresis patterns differentiated between small groups of strains. The correlation of APS protein patterns with habitat suggests that differentiating campylobacters using electrophoretic methods may be more significant than differentiating by routine biochemical tests. Furthermore, the marked differences revealed by electrophoresis between porcine campylobacters and bovine and ovine campylobacters indicate that pigs are unlikely to serve as a source of infection for cattle and sheep and vice versa.

Campylobacters derived from the genital tract of cattle with infectious infertility all produced the same APS patterns (Group I), irrespective of whether they were biochemical type A or B; campylobacters from aborted cattle or sheep foetuses and from cattle faeces produced patterns similar to Group I but differing in at least one band (Group II). Thus APS patterns of isolates from these animal species may be of use in diagnosis, though differences are slight. Enzyme patterns revealed no differences.

Campylobacters are present in large numbers in the gut of pigs suffering from swine dysentery and have been suggested as the causative organism. As they are also present, though in smaller numbers, in healthy pigs, it is important to know if the isolates from diseased and healthy animals differ. That electrophoresis revealed no correlation with porcine disease can be explained in one of three ways. (i) Campylobacters in diseased pigs are mostly pathogenic types, unlike those in healthy pigs, and, though different from one another, are very similar with regard to electrophoresis as well as biochemical reactions so that differences have not yet been regularly detected. (ii) Only non-pathogenic campylobacters were isolated by us from both healthy and diseased pigs, even when pathogenic types were 
present. (iii) There is no qualitative difference in the campylobacter population of healthy and diseased pigs.

Florent (1957) and Deas (1960) found that some of their campylobacter isolates from pigs did not produce $\mathrm{H}_{2} \mathrm{~S}$ from their routine growth medium (Florent used semisolid Martin's broth and Deas used tryptose phosphate broth). All the porcine campylobacters examined by Davis (196I), and us, produced $\mathrm{H}_{2} \mathrm{~S}$ in Albimi brucella broth; Andress \& Barnum (I968) reported similar findings. Thus porcine strains that do not produce $\mathrm{H}_{2} \mathrm{~S}$ may be less widespread than the results of Florent and Deas suggest. In view of this, the intensive examination of isolation plates throughout the present work, and the study of many isolates from this laboratory and elsewhere, we consider it unlikely that we had an unrepresentative collection. We have insufficient evidence to choose between the first and last alternatives but, because the electrophoretic separation of malate dehydrogenase detected differences in the fine structure of that protein, we favour the last explanation; that is there is no qualitative change in the type of campylobacter in the gut of pigs when they succumb to dysentery. Cultural studies by Hurvell \& Reiland (I970) and transmission experiments by various workers (reviewed by Harris \& Glock, I97I) support this conclusion. Our minds are still open on the question of whether campylobacters play an important role in swine dysentery, since, in common with many workers, we found many more campylobacters in animals with swine dysentery than in healthy animals.

We thank Dr N. S. Barron, Agricultural Department and Mr P. Cockburn, Upperwood Farm, Reading University; Mrs A. Gush and Mr R. M. Loosemore, Veterinary Investigation Centre, Coley Park, Reading; Mr A. D. Osborne, Department of Veterinary Medicine, Bristol University; Dr D. R. Melrose, Meat and Livestock Commission; Mr D. L. Stewart, Ministry of Agriculture, Shinfield; for helpful discussions and for providing animal material and cultures. We are grateful to $\mathrm{Mr} \mathrm{M}$. Crowder for his technical assistance and excellent photography. We also wish to thank the Meat and Livestock Commission for a research studentship which enabled this work to be undertaken.

\section{REFERENCES}

Andress, C. E. \& Barnum, D. A. (1968). Pathogenicity of Vibrio coli for swine. II. Experimental infection of conventional pigs with $V$. coli. Canadian Journal of Comparative Medicine and Veterinary Science 32, 529-532.

Bond, J. M. (I957). Characteristics of colonial forms of Vibrio fetus. American Journal of Veterinary Research I8, 449-455.

Broome, J. (1963). A rapid method of disk electrophoresis. Nature, London 199, 179-180.

Clarke, J. T. (I964). Simplified 'disc' (polyacrylamide gel) electrophoresis. Annals of the New York Academy of Sciences I21, 428-436.

Cruickshank, R. (1965). Medical Microbiology, i ith edn. London: Livingstone.

DAvis, B. J. (1964). Disc electrophoresis. II. Method and application to human serum proteins. Annals of the New York Academy of Sciences 121, 404-427.

Davis, J. W. (1961). Studies on swine dysentery. Journal of the American Veterinary Medical Association $138,47 \mathrm{I}-473$.

DEAs, D. W. (1960). Observations on swine dysentery and associated vibrios. Veterinary Record 72, 65-68.

DOYLE, L. P. ( I948). The etiology of swine dysentery. American Journal of Veterinary Research 9, 50-51.

Firehammer, B. D. \& Border, M. (I968). Isolation of temperate bacteriophages from Vibrio fetus. American Journal of Veterinary Research 29, 2229-2235.

Florent, A. (1953). Isolement d'un vibrion saprophyte du sperme du taureau et du vagin de la vache (Vibrio bubulus). Comptes rendus des séances de la Société de biologie 147, 2066-2069. 
Florent, A. (1957). Analogies entre certaines souches de Vibrio coli et certaines souches de Vibrio foetus. Adaption des premières à l'intestin de la bête bovine. Comptes rendus des séances de la Société de biologie I5r, $1055-1057$.

Florent, A. (1959). Les deux vibrioses genitales de la bête bovine: la vibriose venerienne, due a $V$. foetus venerealis, et la vibriose d'origine intestinale due a $V$. foetus intestinalis. Proceedings of the XVIth International Veterinary Congress, Madrid 2, 489-493.

Florent, A. (1963). Apropos des vibrions responsables de la vibriose genitale des bovins et des ovins Bulletin, Office International des Epizooties 60, 1063-1074.

HAAS, H., DAVIDSON, Y. \& SACKS, T. (1972). Taxonomy of Mycobacteria studied by polyacrylamide-gel electrophoresis of cell proteins. Journal of Medical Microbiology 5, 3i-37.

Harris, D. L. \& Glock, R. D. (1971). Swine dysentery: a review. Iowa State University Veterinarian 33 , 4-II.

Hurvell, B. \& ReILAND, S. (I970). Vibrio coli hos grisar. Nordisk veterinärmedicin 22, 456-462.

KenNedy, S. I. T. \& Fewson, C. A. (1968). Enzymes of the mandelate pathway in bacterium N.C.I.B. 8250. Biochemical Journal 107, 497-506.

KING, E. O. (I962). The laboratory recognition of Vibrio fetus and a closely related Vibrio isolated from cases of human vibrosis. Annals of the New York Academy of Sciences 98, 700-7I I.

LAwson, J. R. (1959). Vibriosis. In Infectious Diseases of Animals. Diseases due to Bacteria. Edited by A. W. Stableforth and A. Galloway. London: Butterworths.

LUND, B. M. (1965). A comparison by the use of gel electrophoresis of soluble protein components and esterase enzymes of some group D streptococci. Journal of General Microbiology 40, 4I3-4I9.

Mohanty, S. B., Plumer, G. J. \& Faber, J. E. (I962). Biochemical and colonial characteristics of some bovine vibrios. American Journal of Veterinary Research 23, 554-557.

MOORE, B. (1954). Observations on a group of anaerobic vaginal vibrios. Journal of Pathology and Bacteriology $67,416-423$.

Morris, J. A. (1971). Studies on Campylobacter spp. (microaerophilic vibrios). Ph.D. Thesis, University of Reading.

Morris, J. A. \& PARK, R. W. A. (I970). The use of polyacrylamide gel electrophoresis of cell proteins to differentiate between microaerophilic vibrios. Journal of Applied Bacteriology 33, iv.

Morris, J. A. \& PARK, R. W. A. (I97I). The isolation of microaerophilic vibrios. In Isolation of Anaerobes, pp. 207-2 I7. Edited by D. A. Shapton and R. G. Board. London: Academic Press.

NorrIS, J. R. (1964). The classification of Bacillus thuringiensis. Journal of Applied Bacteriology 27, $439-447$.

Park, R. W. A., Munro, I. B., Melrose, D. R. \& Stewart, D. L. (I962). Observations on the ability of two biochemical types of Vibrio fetus to proliferate in the genital tract of cattle and their importance with respect to infertility. British Veterinary Journal 1r8, 41 1-420.

PeJTSCHEV, P. (1969). Ein Fall von Vibrio fetus bei Rattus norvegicus. Zentralblatt für Veterinärmedizin, Reihe B 16, 480-482.

Plastridge, W. N., Williams, L. F. \& Trowbridge, D. G. (I964). Antibiotic sensitivity of physiologic groups of microaerophilic vibrios. American Journal of Veterinary Research 25, 1295-1 299.

RAZIN, S. \& RoTtem, S. (1967). Identification of Mycoplasma and other microorganisms by polyacrylamidegel electrophoresis of cell proteins. Journal of Bacteriology 94, I807-1810.

Rosett, T. (1965). Cooling device for use with a sonic oscillator. Applied Microbiology 13, 254-256.

SACKs, T. G., HAAS, H. \& RAZIN, S. (1969). Polyacrylamide-gel electrophoresis of cell proteins of Enterobacteriaceae. A possible taxonomic aid. Israel Journal of Medical Sciences 5, 49-55.

Sebald, M. \& Véron, M. (1963). Teneur en bases de l'ADN et classification des vibrions. Annales de l'Institut Pasteur 105, 897-910.

SöDERLIND, O. (1965). The isolation of Vibrio coli from pigs. Veterinary Record 77, 193-196.

Thouvenot, H. \& Florent, A. (1954). Étude d'un anaérobie du sperme du taureau et du vagin de la vache, Vibrio bubulus Florent 1953. Annales de l'Institut Pasteur 86, 237-24I.

Watson, W. A., Hunter, D. \& Bellhouse, R. (1967). Studies on vibrionic infection of sheep and carrion crows. Veterinary Record 81, 220-226.

Whenham, G. R., Carlson, H. C. \& Askel, A. (1961). Avian vibrionic hepatitis in Alberta. Canadian Veterinary Journal 2, 3-7. 